УдК 330.342:338.2

A. A. Терешенко,

к. держ. упр., дочент, дочент кафедри менеджменту та публічного адміністрування,

Харківський начіональний університет будівничтва та архітектури (ХНУБА), м. Харків

ORCID ID: 0000-0003-0633-0097

DOI: $10.32702 / 2306-6814.2020 .3 .128$

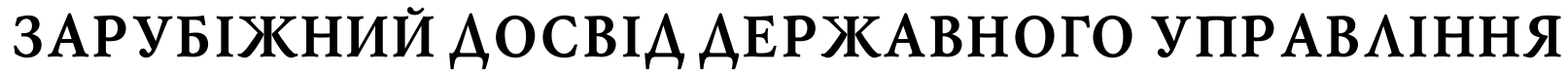

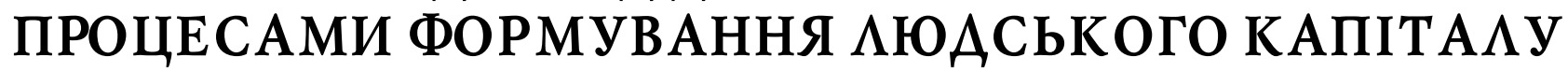

\author{
D. Tereshchenko, \\ $\mathrm{PhD}$ in Public Administration, Associate Professor, Associate Professor of management and public \\ administration Department, Kharkiv National University of Civil Engineering and Architecture
}

\section{FOREIGN EXPERIENCE OF GOVERNMENT CONTROL OF PROCESSES OF HUMAN CAPITAL FORMATION}

У статті досліджено зарубіжний досвід державного управління формуванням людського капіталу. Головну увагу зосереджено на особливостях охорони здоров'я, освіти, соціального захисту та гарантування екологічної безпеки у країнах Європи, США. 3 'ясовано, що в розвинених країнах світу основними тенденціями у державному управлінні формуванням людського капіталує демократизація, інтернаціоналізація, децентралізація; використання правових механізмів регулювання розвитку відносин людини і суспільства; упровадження державно-громадського управління. На основі одержаних результатів дослідження визначено основні напрями вдосконалення механізмів державного управління формуванням людського капіталу в Україні, зокрема вивчення науково обгрунтованих принципів і методів формування людського капіталу у світі та впровадження механізмів їх реалізації в Україні на основі інноваційних стратегій, системного використання державою важелів соціально-економічного стимулювання.

The article examines the foreign experience of government control of human capital formation. The primary focus is concentrated on special features of health care, education, social protection and maintaining of environmental safety in European countries and the USA. It is noted that the tendency for integration of the postindustrial society system into socio-economic and socio-political relations contributes to reforming of government control of formation and development of human capital in Ukraine. It is found that in the advanced countries the main tendencies in government control of human capital formation are democratization, internationalization, decentralization; application of legal mechanisms of development regulation of human and society relations; implementation of government and public control.

It is justified that there is the necessity for Ukraine to take into account positive foreign experience, approved by the time and practice, regarding reduction of government control field in education and health care spheres, establishment of specialized control subjects with active participation of society, implementation of optimum shapes and methods of government control of relation system "human-authority-society", strengthening of transparency bases. Based on the obtained results of the research, the principal areas of improving of government control mechanisms of human capital formation for the purpose of European integration and processes of innovative development of the national economy in Ukraine are determined, particularly study of scientific-based principles and methods of human capital formation in the world and implementation of mechanisms of their realization in Ukraine on the base of innovative strategies, systematic use of levers of socio-economic encouragement by the state. It is noted that one of the most critical task of government control of human capital formation is provision of coordinated actions in all fields of the social life and the adequate definition of the role of central, regional and local authorities and appropriate authorities for control of education, culture, health care, social protection of the population, ecological safety for the human life.

КлючоВі слова: держаВне упраВління, інновачійна економіка, екологічна безпека, людський капітал, охорона здоров'я, осВіта, соціально-економічне благополуччя.

Key words: government control, innovative economy, ecological safety, human capital, health care, education, socio-economic well-being.

\section{ПОСТАНОВКА ПРОБАЕМИ}

Головне багатство суспільства - людський капітал зйого індивідуальними цінностями, знаннями, відповідною кваліфікацією та надбаннями, є основою забез- печення розширеного відтворення благ та послуг, розвитку сучасного ринку праці та найбільш важливою умовою інноваційного розвитку економіки в Україні. Розвиток суспільства, заснованого на знаннях, висуває 
принципово нові вимоги до якості людського капіталу i, відповідно, до управління його фооруванням.

У цьому контексті важливого значення набуває вивчення позитивного досвіду зарубіжних країн у сфрері державного управління процесами фрормування і розвитку людського капіталу.

\section{АНА $\Lambda$ IЗ ОСТАНHIX АОС $А$ ІЖЕНЬ І ПУБ АІКАЦІЙ}

Проблеми формування людського капіталу у сферах освіти, охорони здоров'я, соціального захисту, екологічної безпеки в межах ефективного державного управління сьогодні вивчаються багатьма дослідниками. Серед них можна назвати О.В. Баєву, В.О. Мартиненко, І.М. Сікорську, М.В. Співак, І.В. Тустановську, С.В. Григанську, І.М. Грищенко, П.О. Фесянова, М.А. Хвесик, С.О. Шевченко та ін. Проте, на думку автора, на сучасному етапі державотворення недостатньо імплементується зарубіжний досвід під час формування державної комплексної політики, спрямованої на фрормування людського капіталу, що і визначає потребу наукових пошуків з даного напряму.

\section{ПОСТАНОВКА ЗАВААННЯ}

Мета статті - узагальнення зарубіжного досвіду державного управління в конкретних сфрерах фрормування людського капіталу (освіта, охорона здоров'я, соціальний захист, екологічна безпека) та обгрунтування доцільності його застосування в Україні.

\section{ВИКААА ОСНОВНОГО MATEPIA $\Lambda$ У}

У період зміни технологічного укладу, стрімкого розвитку нових способів виробництва, провідної ролі інноваційного шляху розвитку одне з найголовніших завдань - пошук шляхів формування відповідного сучасним умовам людського капіталу.

На жаль, показники стану інноваційних процесів і використання їх у економіці в Україні залишаються надзвичайно низькими, науково-технічні розробки та їх впровадження сьогодні - одна з найбільш нерегульованих сфер суспільного життя. Серед причин такого занепаду інтелектуального потенціалу слід назвати не тільки недостатній рівень фрінансування, але й відсутність єдиної продуманої державної підтримки інноваційних процесів [1, с. 203]. Як свідчить досвід зарубіжних країн, для підвищення рівня інноваційної активності економіки необхідно створити умови для ефективного формування і використання людського капіталу в інноваційному розвитку.

Найважливішим чинником інноваційного розвитку $є$ освітня складова людського капіталу. Саме якість освіти багато в чому визначає, наскільки успішно людина зможе реалізуватися в професійному плані і у суспільному житті. Система державного управління освітою притаманна будь-якій країні, але кожна країна має свої особливості та визначає власні засоби впливу на сфреру освіти. Так, наприклад, "в Великобританії, Швейцарії запроваджено дворівневе управління, засноване на поєднанні централізованого і місцевого. В Австрії, Нідерландах, Швеції діє трирівнева система управління освітою, що поєднує централізоване управління з регіональ- ним і місцевим. У Німеччині та Італії велику роль в управлінні освітою відіграють місцеві органи влади. У Франції, де протягом багатьох років освіта була однорівневою, централізованою, нині намагаються перейти до її децентралізації [2, с. 38]".

Вища освіта Данії, Норвегії характеризується (за окремими винятками) державним рівнем управління. Нечисленні приватні вищі навчальні заклади одержують від держави субсидії. Держави виявляють високий рівень відповідальності за стан вищої освіти на різних рівнях: законодавчому, здійсненні фінансування, участі у міжнародних об'єднаннях, забезпеченні співробітництва вищої школи та підприємницьких структур у науково-дослідницькій діяльності [3].

Важливо наголосити, що паралельно з управлінськими структурами, але в тісному зв'язку з ними в багатьох зарубіжних країнах функціонують координаційні органи, що вирішують важливі завдання з управління навчальними закладами. У США - координаційні ради на рівні штатів; у Франції - Національна рада освіти і наукових досліджень; у Великобританії - Комітет віце-канцлерів і ректорів університетів тощо [4].

Контроль у сорері вищої освіти у США є прикладом децентралізованої моделі контролю з широкими контрольними повноваженнями місцевих органів (на рівні штатів, округів), а також широким залученням недержавних об'єднань. "Система вищої освіти США побудована на фундаменті вільної та мобільної координації освітніх організацій, що також зумовлює і специфіку контролюу відповідній сорері. Федеральний уряд США не має права встановлювати загальнодержавну систему освіти, в т. ч. й вищої, визначати навчальні програми, плани для освітніх закладів (поправка 10 до Конституції США). Відповідні питання - це прерогатива влади штату чи округу [5, с. 314]".

Можна вести мову про фрормування кількох суб'єктів контролю у сорері вищої освіти у США: 1) загальнодержавний рівень - Міністерство освіти, департамент освіти (з мінімальними повноваженнями переважно фрормального характеру); 2) регіональний рівень - влада штатів, округів; 3) спеціалізований рівень - спеціалізовані суб'єкти (наприклад, Рада з акредитації вищої освіти (CHEA), Національний дорадчий (консультативний) комітет з інституційної якості, цілісності та чесності освіти, Агенція з оцінювання акредитаційних агенцій (комісій), регіональні асоціації (агенції) тощо). Слід зазначити, що роль відповідних недержавних об'єднань $\epsilon$ досить значною не тільки у контролі, а й взагалі в управлінні вищою освітою у США. Їх називають "другою силою", яка, поряд із "першою силою" (Міністр освіти та інші посадові особи Міністерства, які здійснюють керівництво департаментами Міністерства, президенти та ректори вищих навчальних закладів" [6, с. 93], формують інституціональну та державну політику вищої освіти США.

Слід акцентувати увагу, що підготовка фрахівців всіх рівнів в США не закінчується завершенням навчання в школі або вузі, а продовжується впродовж всієї трудової діяльності, перетворюючись, по суті, в безперервний процес. Сфрера підготовки кадрів функціонує як система безперервної освіти ("Life - long education"). Си- 
мулюється активізація співробітництва ВН3 і підприємств у сорері підготовки кадрів [7, с. 90].

Останніми десятиріччями розширення автономії освітніх установ стало світовою тенденцією. Одержуючи автономію, освітні установи беруть на себе відповідальність за якість навчання. Яскравим прикладом можна назвати освітні установи Нідерландів, які декларують, що якість освіти - це їхні власні завдання й обов'язок і що інспекторські служби повинні обмежити свою діяльність оцінюванням загальних досягнень школи в цій царині [8, с. 75]. 31985 року у Нідерландах існує чіткий розподіл контролюу соері вищої освіти між державою та недержавними ("приватними") установами. Загальний стан розвитку вищої освіти у країні контролює Міністерство освіти і спеціалізований орган Інспекція з вищої освіти, повноваження ж контролю щодо безпосереднього розвитку вищої освіти, навчального процесу, якості освіти, її відповідності потребам часу, потребам ринку праці зосереджено в асоціації співробітництва університетів Нідерландів (ACIH) та Ради не університетської освіти [9, с. 175].

Гармонійним і зваженим шляхом поєднання зусиль центральної, регіональної та місцевої влад в управлінні освітою йшла Німеччина. Тенденція щодо деценралізації виявляється в семидесятих роках XX ст., коли були створені нові державні органи управління: Міністерство науки та освіти, Комітет з наукових досліджень та питань освіти, Рада по освіті, Наукова рада [10]. Історично в Німеччині існувала "змішана" система, яка має структури децентралізації та централізації управління, упорядковує й зміцнює централізовану управлінську підструктуру, що має привести до певного підсилення якісної складової управління та консолідації всіх його учасників.

Сьогодні на провідні позиції у сфері освіти у світі вийшла Японія. Як свідчать результати досліджень, феномен японської освіти полягає в тому, що абсолютна кількість молоді продовжує свою освіту в повній середній школі (понад $90 \%$ ). Японія найосвіченіша країна світу. Вже зараз $95 \%$ японців мають середню освіту. Першими в світі вони досягли "всезагальної середньої грамотності". До 25 років більше $40 \%$ японських юнаків і дівчат отримують вищу освіту. Рівень освіти винятково високий у всіх прошарках суспільства [11] Широкомасштабні реформи передбачають зміну політики фрінансування ЗВО. Університетські корпорації фрінансуються на 79\% з держбюджету (приватні 3ВО також отримують субсидії від держави). Вони зобов'язані подавати звіти про свою діяльність і прагнути до високих показників академічної продуктивності. Університетські корпорації розвиваються на основі шестирічних планів. Фінансування корпорацій здійснює Міністерство освіти, культури, спорту, науки й технологій, воно залежить від результатів оцінки виконання ними затверджених планових показників [12].

Отже, узагальнений аналіз зарубіжного досвіду державного управління у сфері вищої освіти дозволяє стверджувати, що його вивчення $€$ необхідним задля уникнення проблемних питань та запозичення позитивних напрацювань. Для підвищення ефективності державного управління у сорері вищої освіти в Україні видається доцільним урахування позитивного зарубіжно- го досвіду у частині: децентралізації, що передбачає передачу більшої частини контрольних повноважень місцевим органам державної влади; зменшення загальної кількості суб'єктів державного контролю і створення спеціалізованих суб'єктів зі "змішаним" складом (із залученням професійних громадських об'єднань, освітянської громадськості); визначення в якості безпосередньої мети забезпечення якості вищої освіти й розширення автономії вищих навчальних закладів щодо вирішення інших питань; здійснення державного фінансування, забезпечення участі у міжнародних об'єднаннях та співробітництва вищої школи та підприємницьких структур у науково-дослідницькій діяльності.

Крім освіти, найважливішою сферою формування i розвитку людського капіталу $є$ охорона здоров'я. На сьогодні можна виділити три основні системи охорони здоров'я у світі: державна система (Великобританія); страхова система (представлена в таких європейських країнах, як Франція, Австрія, Бельгія, Швейцарія, деяких країнах Латинської Америки, Японії); приватна система (Сполучені Штати Америки). Проте у розглянутих країнах зазначені системи не представлені в чистому вигляді. Навіть у країнах з державною системою охорони здоров'я $є$ організації, що здійснюють приватне медичне страхування. Державна система охорони здоров'я розвивається як напрям соціальної політики. У результаті держава посилює свій вплив і контроль над діяльністю медичних і страхових організацій. Наприклад, у Великобританії основна частина коштів надходить з державного бюджету і розподіляється зверху вниз по управлінській вертикалі.

Страхова система заснована на принципах солідарності. Наприклад, у Німеччині діє одна з найбільш розвинених систем соціального медичного страхування, якою охоплено понад 90\% населення. Система обов'язкового страхування здійснює свою діяльність через страхові організації - лікарняні каси. Приватна система медичного страхування найбільш широко представлена у США. Вона характеризується децентралізованістю, високим розвитком інфраструктури страхових організацій та відсутністю державного регулювання. Приватною формою медичного страхування охоплено понад 80\% населення. У США діє приблизно 1500 приватних страхових компаній [13].

Система охорони здоров'я багатьох країн рухається в напрямку профрілактичної медицини. Тим самим держави в якості пріоритетних цілей визначають досягнення поліпшення здоров'я, збільшення тривалості життя населення через забезпечення профрілактики захворювань, підвищуючи соціальну відповідальність населення. Так, наприклад, в Австрії з 2005 року Міністерство охорони здоров'я впровадило рекомендації з превентивної медицини, ключовим пунктом яких стало проведення обстежень груп ризику. Такі щорічні медичні огляди оплачуються державними страховими фондами. $98 \%$ населення Австрії мають медичну соціальну страховку.

У багатьох країнах Європи, зокрема Німеччині, Франції та Нідерландах, реалізація контролю й регламентації медичних послуг у системі державного управління та контролю якості здійснюється за допомогою роботи комерційних страхових систем. У Швеції, Японії 
та Австралії - за допомогою системи державного страхування, у Канаді та Великій Британії - прямим державним забезпеченням.

Вивчення зарубіжного досвіду державного управління системою охорони здоров'я в різних країнах, дозволяє визначити основні напрями щодо забезпечення якості медичних послуг у нашій країні. Серед них слід виокремити такі: удосконалення форм і методів державного управління галуззю охорони здоров'я, здійснення державного фінансування, забезпечення проведення наукових розробок та розвиток інновацій у соері медичних послуг; створення ефективної системи контролю якості медичних послуг; посилення мотивації праці медичних працівників; розробка іреалізація державних програм, що спрямовані на профрілактику та підтримку здоров'я населення.

Однією з ключових сфрер формування і розвитку людського капіталу є забезпечення соціального захисту населення. Водночас цікавим є досвід США. В останні роки державна політика США в більшій мірі характеризується перенесенням центру уваги з заходів допомоги нужденним працездатним особам на заходи щодо підвищення їх конкурентоспроможності на ринку праці і створення умов для їх самореалізації шляхом розширення можливостей отримання кредиту на освіту; розробки спеціальних програм, спрямованих на отримання інформації про професійне навчання тощо.

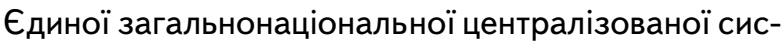
теми соціального забезпечення у США не існує. Вона утворюється з різного роду програм, регламентованих або федеральними органами, або законодавством штату, або їх спільними зусиллями. Окремі програми приймаються органами місцевої влади. Державна система соціального забезпечення чітко підрозділяється на два напрями: соціальне страхування і соціальна допомога. Сьогодні в США існує понад декілька значних і понад 70 обмежених державних програм допомоги. Головними серед них $\epsilon$ - програма забезпечення гарантованого доходу, програма допомоги сім'ям з дітьми, продовольча програма, програма житлових субсидій і програма медичної допомоги (Медикейд). Що відрізняє США від інших країн, так це надзвичайно велика кількість приватних (комерційних) соціальних організацій. Вони фрінансуються як за рахунок благодійних внесків, надходжень як від приватних осіб, так і урядових асигнувань на окремі програми. Ці організації відрізняються не тільки характером своєї діяльності, специфікою послуг, але й масштабом дій в межах громади, регіону i країни. Основною ланкою в цій системі виступають так звані соціальні агентства (Американська служба сім'ї, Організація з надання послуг сім'ям, Лютеранська соціальна служба та ін.). До системи соціального захисту дітей та молоді входять й так звані неприбуткові організації [14]. Також у США існують програми медстрахування для літніх людей та інвалідів, для малозабезпечених родин [15, с. 108].

Під час аналізу системи і особливостей надання соціальних послуг, зокрема і здійснення соціального супроводу сімей (осіб), які перебувають у складних життєвих обставинах, привертає увагу насамперед досвід розвинених країн, як Німеччина, Франція, Великобри- танія та Італія, оскільки ці країни не лише входять до тридцяти країн із найвищим рівнем соціального розвитку, ає також європейськими, що важливо враховувати з огляду на посилення євроінтеграційних тенденцій сучасної України.

Так, наприклад, формування систем соціального захисту Німеччини, заходи інституту допомоги сім'ям (особам), молоді, дітям здійснюють у Німеччині державні й громадські організації, які тісно співпрацюють на основі принципу субсидіарності, згідно з яким держава виконує лише ті функції, які не можуть взяти на себе громадські організації і які не належать до компетенцій місцевих органів, що надає перевагу недержавним організаціям перед державними [16, с. 212]. У Німеччині до надання соціальних послуг часто залучаються волонтерські організації, які не мають офіційного статусу [17, с. 220]. Німецьке соціальне ринкове господарство, пройшовши у своєму розвитку фазу зближення зі скандинавською моделлю держави загального добробуту і не зумівши зупинити шквал соціальних видатків, почало переформатування концепції соціальності на принципи самостійного забезпечення індивідами гідного рівня життя. Врешті-решт, німецькі конструктори соціальної держави дійшли висновку, що соціальна орієнтація ринкової економіки полягає не в тому, щоб здійснювати максимально широку соціальну допомогу, а в тому, щоб створити такі умови, коли такої допомоги буде потребувати мінімальна кількість громадян [18, с. 58].

Основним джерелом фінансування системи соціального захисту у Франції слугують страхові внески працівників і роботодавців. Виняток становить страхування від безробіття й сімейні виплати, частка державних дотацій в яких істотно вища, ніж в інших галузях соціального забезпечення, а також страхування від нещасних випадків, яке фінансується виключно за рахунок коштів роботодавця. У Великобританії важливу роль у регулюванні питань соціального обслуговування громадян відіграють відповідні принципи. Так, до принципів надання соціальних послуг віднесено такі: повна автономність і децентралізація суб'єктів надання соціальних послуг, соціальна інтеграція, розробка соціальних послуг на місцях для задоволення конкретних потреб, відповідальність органів місцевого самоврядування за якість наданих послуг [19, с. 21-22].

Структура фінансування системи соціального захисту Великобританії визначається поділом цієї системи на дві частини: національну охорону здоров'я та національне соціальне страхування. Перша фрінансується на 90\% з державного бюджету, а друга - за рахунок страхових внесків найманих працівників і підприємців. Окрім охорони здоров'я, податкове фрінансування характерне для забезпечення від нещасних випадків на виробництві, а також сімейних виплат. Швеція та США для вирішення проблеми орінансування соціальних потреб використовують принцип соціальної солідарності, який полягає в тому, що всі громадяни в рівності і незалежно від соціального статусу беруть участь у фрінансуванні системи соціального захисту, вносячи пропорційний своїм прибуткам внесок. Значний "тиск" подібної системи (рівень оподаткування в Швеції $є$ одним із найви- 
щих у світі) забезпечується високим ступенем соціальної захищеності населення.

У країнах Західної Європи та США існують практика реалізації програми соціальногожитла. Так, у Німеччині малозабезпеченим громадянам надають грошову допомогу для самостійної оренди житла в приватному секторі. В США запроваджено систему субсидіювання, згідно з якою спочатку державну цільову допомогу отримував орендодавець, а згодом її отримувачем став орендар. Сектор соціального житла в Голландії, Швеції, Великобританії, Данії, Франції і Фінляндії становить 15-35 \% від загального житлового фонду. В європейських державах на соціальні житлові програми виділяються значні кошти: від 0,1-0,3 \% ВВП, в Італії і Греції до 1,2-1,4% ВВП, у Франції - 1,9 \% ВВП [20].

Отже, на основі вищевикладеного матеріалу можна зробити наступні висновки щодо покращення державного управління соціальною сферою: надання більшої самостійності регіонам у формуванні бюджету та програм розвитку, підтримка в цьому центральних органів влади; використання різноманітних фрорм державно-приватного партнерства; створення фондів розвитку для ефективного забезпечення соціальної сфери; створення механізмів соціального захисту не лише на підтримку уразливих соціальних груп, а й на реалізацію довготривалих програм щодо кардинальної зміни основ системи соціального захисту, підвищення ії̈ ефективності.

Важлива складова формування людського капіталу - забезпечення екологічної безпеки. На сьогодні у багатьох країнах світу щодо розв'язання проблем державного регулювання забезпечення екологічної безпеки нагромаджено значний досвід, а саме - створено ефективні організаційні структури і дієвий механізм правового регулювання забезпечення екологічної безпеки та раціонального використання природних ресурсів.

Досить вдалим прикладом $є$ регулювання охорони навколишнього природного середовища та природокористування у США, де з кінця 60-х рр. XX ст. забруднення навколишнього природного середовища стало однією з основних проблем. Цільові заходи з охорони довкілля тут визначає федеральне Агентство з охорони природи, а кожний штат окремо пропонує конкретні заходи щодо їх реалізації, пов' язуючи їх з планами розвитку галузей. Ефективним засобом контролю за викидами є запровадження Агентством з охорони навколишнього середовища у США "дозволів" на допустиму кількість забруднювальних речовин, який є меншим, а ніж встановлений для них ліміт на продаж своїх прав іншим фрірмам [21, с. 44].

В європейських країнах найбільш поширеним у рамках економічного методу регулювання природоохоронною діяльністю $є$ наступні інструменти. Це екологічні платежі за забруднення атмосферного повітря, водних ресурсів, шумове забруднення, утилізацію відходів тощо. Надання підприємствам свободи вибору альтернативних рішень щодо плати за забруднення середовища створює певні передумови не лише для зменшення вартості боротьби із забрудненням, а й зменшує виробничі витрати в цілому Як інструмент державного регулювання природокористування у країнах з ринковою економікою існують податки за шкідливу продукцію (різні види пального, тару, міндобрива, пестициди, миючі засоби тощо) [22].

У розвинених країнах повноваження з питань державного регулювання природокористування та охорони навколишнього природного середовища між органами центральної, регіональної та місцевої влади розподіляються по-різному. У такій федеративній державі, як Німеччина, регіональним органам влади делеговано чітко визначені повноваження, тоді як у менш "жорсткій" федерації, як США, розподіл повноважень між владою штатів і федеральним урядом не завжди чітко визначений. В унітарних державах ступінь централізації управління теж різний: найбільший ступінь децентралізації управління існує у Великобританії, Нідерландах та Швеції, менший - у Франції [23, с. 24].

У країнах Європейської співдружності екологічне управління поєднує збалансовані адміністративноконтрольні та фрінансово-економічні важелі, які дають змогу ефективно регулювати питання охорони довкілля та забезпечення екологічної безпеки. У червні 1993 р. у рамках ЄС були прийняті основні принципи і положення екологічного обліку, які набули чинності в квітні 1995 р. Змінилися і пріоритети у боротьбі $з$ забрудненням атмосфери. Так, головні програми спрямовано не на введення в дію очисного обладнання, а на створення екологічно чистих технологій. У цих країнах діють понад 200 чітких механізмів реалізації екологічного законодавства, застосовується близько 150 видів екологічних податків, структура і тарифні ставки яких затверджено національними парламентами [24, с. 395]. Зауважимо, що ці механізми мають свої специфрічні риси, обумовлені особливостями власних екологічних проблем країни, а також сформованістю політичного, економічного, соціального середовища.

В Японії існує практика "добровільних угод" між екологічними інспекторами та природокористувачами, що впливають на стан довкілля. Їх укладання спирається на переконання, довіру і традиції адміністративного керівництва, що передбачає проведення перемовин між природокористувачами і тими, хто регулює їх вплив на довкілля, перед наданням дозволу на природокористування [25].

Зарубіжна практика свідчить, що основою всієї системи захисту навколишнього природного середовища $\epsilon$ активне державне регулювання, в якому пріоритети надаються економічному стимулюванню та підтримці підприємництва, що розвивається в напрямі екологізації виробництва. Зарубіжний досвід державного регулювання у сорері природокористування та охорони навколишнього природного середовища свідчить про необхідність поєднання економічних методів з адміністративними та правовими (пільги та економічна допомога підприємствам, які здійснюють боротьбу із забрудненням; впровадження механізму екологічного страхування).

Таким чином, проведений аналіз зарубіжного досвіду продемонстрував, що в розвинених країнах світу основними тенденціями у державному управлінні формуванням людського капіталу є демократизація, інтернаціоналізація, децентралізація; використання правових механізмів регулювання розвитку відносин людини і 
суспільства; упровадження державно-громадського управління.

\section{ВИСНОВКИ 3 ПРОВЕАЕНОГО АОСАІАЖЕННЯ І ПЕРСПЕКТИВИ

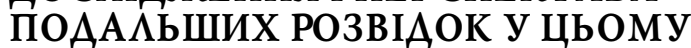 НАПРЯМ}

Аналіз досліджень зарубіжного досвіду дає змогу зробити висновки про те, що найважливішими перешкодами для реалізації ефективного механізму державного управління формуванням людського капіталу в Україні $\epsilon$ недостатнє наукове та фрінансове забезпечення, труднощі та невідповідності у сучасному законодавстві, низький рівень впровадження інноваційних технологій і недостатнє врахування світового передового досвіду. У зв'язку з цим першочерговими завданнями мають стати:

- вивчення науково обгрунтованих принципів і методів державного управління формуванням людського капіталу у світі та впровадження механізмів їх реалізації в Україні на основі інноваційних стратегій, системного використання державою важелів соціально-економічного стимулювання;

- звуження сорери державного контролю у сферах вищої освіти та охорони здоров'я, створення спеціалізованих суб'єктів контролю з активною участю громадськості;

- зміщення акцентів у вирішенні проблем формування людського капіталу з центральних державних структур на регіональні, підвищення ролі недержавних громадських організацій у реформуванні систем освіти, охорони здоров'я, соціального захисту населення, екологічної безпеки;

- підвищення ефективності міжвідомчої взаємодії відповідних органів державної влади та місцевого самоврядування, координації їхніх дій, запровадження інтегрованої системи громадянського суспільства і адекватних йому організаційних структур державного управління, діяльність яких спрямована на фрормування і розвиток людського капіталу на основі уніфікованих мінімальних стандартів таєдиних технологій;

- запровадження європейських форм взаємодії інститутів держави, бізнесу та громадянського суспільства для реалізації дієвих державних програм, спрямованих на формування людського капіталу.

\section{Література:}

1. Антикризове управління національною економікою: монографрія / І. Малий, І. Радіонова, Л. Ємельяненко та ін. / за заг. ред. І. Малого. К.: КНЕУ, 2017. 368 с.

2. Сікорська І.М. Удосконалення державного управління вищою освітою в контексті європейської інтеграції: автореф. дис. канд. наук з держ. упр.: 25.00.02 / Донец. держ. ун-т управління. Донецьк, 2006. 21 с.

3. Supporting the Contribution of Higher Education Institutions to Regional Development: Report of the Oresund Region to the OECD-project / Nielsen Linda, Bexell Goran, Jensen Henrik Toft, Olausson Lennart. Copenhagen, 2005. 132 p.

4. Григанська С.В. Державне регулювання системи вищої освіти в Україні: автореф. дис. канд. наук з держ. упр.: 25.00.02 / Класичний приват. ун-т. Запоріжжя, 2008. 20 c.
5. Баєва О.В. Державно-громадське управління якістю вищої освіти: досвід США. Держава та регіони. (Серія: Державне управління). 2010 . № 2. C. 5-9.

6. Джонстоун Д. Б. Система образования в США: структура, руководство, финансирование. Университетское управление: практика и анализ. 2003. № 5-6 (28). С. 92-102.

7. Шмидт В.Р. Молодой специалист на предприятии и в вузе: опыт модернизации профессионального образования США и Австралии. Труд за рубежом. 2002. № 3. C. $87-100$.

8. Советы и другие фрормы участия общественности в системах образования стран Европейского Союза. М.: Эвридика, 2016. 198 с.

9. Шевченко С.О. Механізм державного та громадського управління якістю вищої освіти: зарубіжний досвід / С.О. Шевченко / / Держава та регіони. - 2007. - № 3. - С. 171-176. - (Серія: Державне управління).

10. Дарманський М.М. Соціально-педагогічні основи управління освітою в регіоні / М.М. Дарманський. - Хмельницький: Поділля, 1996. - 384 с.

11. Курінна М.Г. Особливості змісту загальної освіти в Японії. Науковий вісник Донбасу. 2011. № 2. URL: http://nvd.luguniv.edu.ua/archiv/NN14/11kmgovy.pdf

12. Грищенко І.М. Стан та особливості управління вищою освітою в Японії. Трибуна. 2009. № 9-10. C. $26-29$.

13. Міжнародний досвід реформування системи охорони здоров'я (досвід країн Європейського Союзу). Інформаційна довідка, підготовлена Європейським інформаційно-дослідницьким центром на запит народного депутата України. URL: http://euinfocenter.rada.gov.ua/uploads/documents/29185.pdf

14. Войтенкова Г.Ф., Лебедева Е.Г. Социальная поддержка семей с детьми в США. Народонаселение. 2007. № 4. С. 94-106.

15. Співак М.В. Державна політика здоров'язбереження: світовий досвід і Україна: монографрія. Київ: Ін-т держави і права ім. В.М. Корецького НАН України; Видавництво "Логос", 2016. 536 с.

16. Weigel, H.G. Dritter Sektor. Worterbuch Soziale Arbeit. Kreft/Mielenz. Weinheim/Munchen: Juventa Verlag, 2008. S. 211-213.

17. Боде И. Германия: социальные услуги. Соціальна робота в Україні: теорія і практика. 2013. № 1-2. С. $220-226$.

18. Економічні та гуманітарні напрями розвитку соціальної інфраструктури: монографрія / В.М. Новіков, Н.М. Деєва, Г.А. Дмитренко та ін./ За заг. ред. B.M. Новікова. URL: https://www.idss.org.ua/ public_rus

19. Положительный опыт предоставления социальных услуг в странах Юго-Восточной Европы. URL: http://www.ilo.org/public/russian/region/eurpro/ moscow/info/publ/rus_socserv_delivery_part.pdf, c. $21-22$.

20. Суркова Ю.О. Проблеми впровадження елементів зарубіжного досвіду фрінансування житлового будівництва в Україні. URL: http: / / gisap.eu/ru/node / 234 
21. Тустановська І.В. Застосування права в галузі охорони довкілля в Україні та США (порівняльний аналіз): дис. канд. юрид. наук. Львів, 1998. 180 с.

22. Мартиненко В.О. Досвід країн ЄС щодо сучасних механізмів управління охороною навколишнього середовища в Україні. URL: http:/ /dspace.uabs.edu.ua/ bitstream /123456789/896/1/5.pdf

23. Зеркалов Д.В. Екологічна безпека: управління, моніторинг, контроль Київ: КНТ, Дакор, Основа, 2007. 412 c.

24. Хвесик М.А. Економіко-правове регулювання природокористування / М.А. Хвесик, Л.М. Горбач, Ю.П. Кулаковський. К.: Кондор, 2004. 524 с.

25. Фесянов П.О. Державне регулювання забезпечення екологічної безпеки на регіональному рівні досвід провідних країн світу. URL: http://visnyk.academy.gov.ua/wp-content/uploads/2013/11/2011-420.pdf

\section{References:}

1. Malyj, I. Radionova, I. Yemel'ianenko, L. (2017), Antykryzove upravlinnia natsional'noiu ekonomikoiu [Crisis management of the national economy], KNEU, Kyiv, Ukraine.

2. Sikors'ka, I.M. (2006), "Improving the governance of higher education in the context of European integration", Abstract of Ph.D. dissertation, Public Administration, Donets. derzh. un-t upravlinnia. Donets'k, Ukraine.

3. Nielsen, Linda, Bexell, G. Jensen, H.T. and Olausson, L. (2005), Supporting the Contribution of Higher Education Institutions to Regional Development: Report of the Oresund Region to the OECD-project, Copenhagen, Denmark.

4. Hryhans'ka, S.V. (2008), "State regulation of the higher education system in Ukraine", Abstract of Ph.D. dissertation, Public Administration, Klasychnyj pryvat. unt, Zaporizhzhia, Ukraine.

5. Baieva, O.V. (2010), "Public-Higher Education Quality Management: The US Experience", Derzhava ta rehiony. (Seriia: Derzhavne upravlinnia), vol. 2, pp. 5-9.

6. Dzhonstoun, D.B. (2003), "US education system: structure, leadership, financing", Unyversytetskoe upravlenye: praktyka y analyz, vol. 5-6 (28), pp. 92-102.

7. Shmydt, V.R. (2002), "Young specialist at the enterprise and in the university: the experience of modernization of vocational education in the USA and Australia", Trud za rubezhom, vol. 3, pp. 87-100.

8. EU comission (2016), Sovety y druhye formy uchastyia obschestvennosty $v$ systemakh obrazovanyia stran Evropejskoho Soiuza [Councils and other forms of public participation in the education systems of the countries of the European Union], Evrydyka, Moscow, Russia.

9. Shevchenko, S.O. (2007), "Mechanism of state and public higher education quality management: foreign experience", Derzhava ta rehiony. Seriia: Derzhavne upravlinnia, vol. 3, pp. 171-176.

10. Darmans'kyj, M.M. (1996), Sotsial'no-pedahohichni osnovy upravlinnia osvitoiu $v$ rehioni [Socio-pedagogical bases of education management in the region], Podillia, Khmel'nyts'kyj, Ukraine.

11. Kurinna, M.H. (2011), "Features of the content of general education in Japan", Naukovyj visnyk Donbasu, vol. 2, available at: http://nvd.luguniv.edu.ua/archiv / NN14/11kmgovy.pdf (Accessed 15 Jan 2020).

12. Hryschenko, I.M. (2009), "The status and features of higher education management in Japan", Trybuna, vol. $9-10$, pp. $26-29$.

13. EUINFOCENTER (2005), "International experience in healthcare system reform (European Union experience). Information inquiry prepared by the European Information and Research Center at the request of the People's Deputy of Ukraine", available at: http://euinfocenter.rada.gov.ua/uploads/documents/29185.pdf (Accessed 15 Jan 2020).

14. Vojtenkova, H.F. and Lebedeva, E.H. (2007), "Social Support for Families with Children in the USA", Narodonaselenye, vol. 4, pp. 94-106.

15. Spivak, M.V. (2016), Derzhavna polityka zdorov'iazberezhennia: svitovyj dosvid i Ukraina [National Health Policy: Global Experience and Ukraine], In-t derzhavy i prava im. V.M. Korets'koho NAN Ukrainy; Vydavnytstvo "Lohos", Kyiv, Ukraine.

16. Weigel, H.G. (2008), Dritter Sektor. Worterbuch Soziale Arbeit, Juventa Verlag, Munchen, FRG.

17. Bode, Y. (2013), "Germany: social services", Sotsial'na robota $v$ Ukraini: teoriia i praktyka, vol. 1-2, pp. $220-226$.

18. Novikov, V.M. Deieva, N.M. and Dmytrenko, H.A. (2011), Ekonomichni ta humanitarni napriamy rozvytku sotsial'noi infrastruktury [Economic and humanitarian directions of social infrastructure development], Ptoukha Institute for Demography and Social Studies of the National Academy of Sciences of Ukraine, Kyiv, Ukraine.

19. ILO (2019), "Positive experience in the provision of social services in South-Eastern Europe", available at: http://www.ilo.org/public/russian/region/eurpro/ moscow/info/publ/rus_socserv_delivery_part.pdf (Accessed 15 Jan 2020).

20. Surkova, Yu.O. (2011), "Problems of implementation of elements of foreign experience of housing finance in Ukraine", available at: http://gisap.eu/ru/ node/234 (Accessed 15 Jan 2020).

21. Tustanovs'ka, I.V. (1998), "Application of environmental law in Ukraine and the USA (benchmarking)", Abstract of Ph.D. dissertation, Law, L'viv, Kyiv, Ukraine.

22. Martynenko, V.O. (2006), "Experience of EU countries on current environmental management mechanisms in Ukraine", available at: http:// dspace.uabs.edu.ua/bitstream/123456789/896/1/ 5.pdf (Accessed 15 Jan 2020).

23. Zerkalov, D.V. (2007), Ekolohichna bezpeka: upravlinnia, monitorynh, kontrol' [Environmental safety: management, monitoring, control], KNT, Dakor, Osnova, Kyiv, Ukraine.

24. Khvesyk, M.A. Horbach, L.M. and Kulakovs'kyj, Yu.P. (2004), Ekonomiko-pravove rehuliuvannia pryrodokorystuvannia [Economic and legal regulation of nature management], Kondor, Kyiv, Ukraine.

25. Fesianov, P.O. (2011), "State regulation of environmental security at the regional level: experience of leading countries in the world", available at: http://visnyk.academy.gov.ua/wp-content/uploads/2013/11/2011-420.pdf (Accessed 15 Jan 2020).

Стаття надійшла до редакиї 10.02.2020 p. 